\title{
Clinical Results of a Violet-light Filtering Aspheric Intraocular Lens
}

\author{
Mor Ișı̆̆ı Filtre Eden Asferik Bir Göz İçi Lensinin Klinik Sonuçları

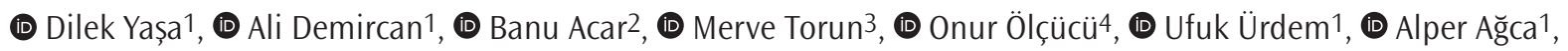 \\ (1) Ahmet Demirok1 \\ ${ }^{1}$ Beyoğlu Eye Diseases Training and Research Hospital, Clinic of Ophthalmology, İstanbul, Turkey \\ 2Batıgöz Hospital, Clinic of Ophthalmology, İstanbul, Turkey \\ 3/ğdır State Hospital, Clinic of Ophthalmology, Iğdır, Turkey \\ ${ }^{4}$ Kırklareli Babaeski State Hospital, Clinic of Ophthalmology, Kırklareli, Turkey
}

\begin{abstract}
Introduction: To evaluate the visual and refractive outcomes after implantation of a monofocal aspheric yellow chromophore intraocular lens (Eyecryl Plus ASHFY600, Biotech Vision Care Pvt. Ltd., Ahmedabad, India).

Methods: Medical records of patients, who underwent cataract surgery and had intraocular lens implantation, were retrospectively analyzed. One eye of each patient was evaluated. Subjective manifest refraction and visual acuity results at 1 week and 1, 3 and 6 months, and intraoperative and postoperative complications were analyzed.

Results: Forty-nine eyes (25 right and 24 left) of 49 patients (31 male and 18 female) were included in the study, At postoperative week 1, best corrected distance visual acuity (CDVA) was significantly increased and within an acceptable range. Uncorrected distance visual acuity (UDVA) and best CDVA were stabilized at the $1^{\text {st }}$ month examination, and there was no significant difference in visual acuity between the $1^{\text {st }}$ month and the $3^{\text {rd }}$ and $6^{\text {th }}$ month examinations. The best CDVA and UDVA at $6^{\text {th }}$ months were $20 / 25$ or better in $93 \%$ and $79 \%$ of patients, respectively. The spherical equivalent of the manifest refraction was within $\pm 1.00 \mathrm{D}$ emmetropia in $96 \%$ of the patients. No complication occurred during or after surgery.

Conclusion: CDVA and UDVA and postoperative refractive results were similar to non-chromophore lenses. The implantation of the Eyecryl Plus ASHFY600 intraocular lens has been evaluated as effective and safe.
\end{abstract}

Keywords: Cataract surgery, emmetropia, violet light, visual acuity, yellow chromophore

\section{öz}

Amaç: Sarı kromoforlu, mor ıșığı kısmen filtre eden, asferik monofokal bir göz içi lensinin (Eyecryl Plus ASHFY600, Biotech Vision Care Pvt. Ltd., India) klinik sonuçlarını değerlendirmektir.

Yöntemler: Katarakt cerrahisi geçirip cerrahi sonunda Eyecryl Plus ASHFY600 model intraoküler lens implantasyonu uygulanan hastaların dosyaları retrospektif olarak incelendi. Her hastanın bir gözü çalıșma kapsamında değerlendirildi. Birinci hafta, 1. ay, 3. ay ve 6 . ay muayenelerindeki subjektif manifest refraksiyon ve görme keskinliği sonuçları ile intraoperatif ve postoperatif komplikasyonlar analiz edildi.

Bulgular: Kırk dokuz hastanın 49 gözü çalışma kapsamına alındı (25 sağ göz ve 24 sol göz, 31 erkek ve 18 kadın). Ameliyat sonrası 1. hafta muayenesinde en iyi düzeltilmiș uzak görme keskinliği anlamlı derecede artmış ve kabul edilebilir derecedeydi. Düzeltilmemiş ve en iyi düzeltilmiş görme keskinlikleri 1. ay muayenesinde stabilize olmuştu ve 1 . ay muayenesi ile 3. ve 6 . ay muayeneleri arasında görme keskinlikleri açısından anlamlı fark yoktu. Altıncı ayda düzeltilmemiş ve en iyi düzeltilmiş görme keskinlikleri hastaların sırasıyla \%79 ve \%93'ünde 20/25 veya daha iyiydi. Manifest refraksiyonun sferik eşdeğeri hastaların \%96'sında $\pm 1,00 \mathrm{D}$ emetropi aralığındaydı. Hiçbir hastada ameliyat esnasında veya sonrasında komplikasyon gelişmedi.

Sonuç: Düzeltilmiş ve düzeltilmemiş görme keskinlikleri ve ameliyat sonrası refraktif sonuçlar kromoforsuz lenslerle benzer olarak tespit edilmiștir. Eyecryl Plus ASHFY600 göz içi lensinin implantasyonu etkili ve güvenli olarak değerlendirilmiştir.

Anahtar Kelimeler: Katarakt cerrahisi, emetropi, mor ışık, görme keskinliği, sarı kromofor 


\section{Introduction}

Ultraviolet light (below $400 \mathrm{~nm}$ ) does not provide useful vision and can lead to retinal damage; so, ultraviolet-blocking intraocular lenses (IOL) have been dominant in cataract surgery after 1980s (1). These lenses are now standard of care and effectively block most of the radiation below $400 \mathrm{~nm}$. In addition, it has been suggested that increasing the absorption spectrum of the IOL to violet or further to blue spectrum may result in better contrast sensitivity and better protection against retinal phototoxicity and associated age-related macular degeneration (AMD) (2).

Although a blue or violet-light filtering IOL may help prevent phototoxic damage that is thought to contribute to the pathogenesis of AMD, it has been suggested by some researchers that such lenses may also result in impaired scotopic vision and color perception (3). However, major differences in the absorption capacities were observed in the violet and blue light range among commercially available violet or blue light filtering IOLs depending on their material properties (4). Thus, it is not correct to think all these lenses as a homogenous subgroup. Filtering properties of each IOL and corresponding clinical effects must be tested individually.

Eyecryl Plus ASHFY600 (Biotech Vision Care Pvt. Ltd., Ahmedabad, India) is a hydrophobic acrylic, aspherical IOL that does not affect quality of scotopic vision due to its unique Natural Yellow Chromophore filters 400 $\mathrm{nm}$ to $440 \mathrm{~nm}$ of light spectrum only. There are no published studies describing clinical outcomes following implantation of this lens.

In this study, we retrospectively analyzed the visual and refractive results after implantation of Eyecryl Plus ASHFY600.

\section{Methods}

This study followed the tenets of the Declaration of Helsinki, and approval was obtained from the Haydarpaşa Numune Training and Research Hospital Clinical Research Ethics Committee (approval number: HHEAH-KAEK 2017/193). Medical records of patients, who underwent cataract surgery and had IOL implantation, were retrospectively analyzed. Patients with diabetes and patients with previous retinal or other ocular pathology were excluded from the analysis. Only one eye of each patient was included in the study.

Uncorrected and corrected visual acuity testing and routine preoperative and postoperative ocular examinations were performed at 1 week, and 1,3 , and 6 months postoperatively. At the preoperative visit, uncorrected distance visual acuity (UDVA), best corrected distance visual acuity (CDVA), manifest refraction, corneal topography, biometry, ocular health evaluation, and other standard preoperative testing were performed. At postoperative week 1, UDVA, CDVA and manifest refraction was performed. UDVA, CDVA, uncorrected near visual acuity and distance corrected near visual acuity (DCNVA) measurements were performed at the $1^{\text {st }}, 3^{\text {rd }}$ and $6^{\text {th }}$ month examinations. A back-illuminated 19 " LED LCD monitor chart with a decimal notation (CC-100 XP, Topcon, Tokyo, Japan) was used for UDVA and DCVA visual acuity measurements. The visual acuities were converted to $\log$ MAR for statistical analysis and converted back to Snellen/decimal notation for presentation. UNVA and DCNVA were measured using a Jaeger test chart at $40 \mathrm{~cm}$.

\section{Surgical Technique}

All surgeries were performed using phacoemulsification with Infiniti Vision System (Alcon Laboratories Inc., Fort Worth, Texas, United States) and R-Evolution (Optikon 2000 SpA, Rome, Italy). After topical anesthesia (Proparakain hydrochloride 0.5\%), a temporal clear corneal incision (2.75 mm) was made. A central, continuous, curvilinear capsulorhexis, approximately $5.5 \mathrm{~mm}$ in diameter was created. Phacoemulsification was performed using torsional or longitudinal ultrasound, followed by irrigation and aspiration of the cortex. The IOL was then implanted in the capsular bag.

\section{Intraocular Lens}

The Eyecryl Plus ASHFY600 IOL is a hydrophobic acrylic lens with a natural chromophore to filter $400 \mathrm{~nm}$ to $440 \mathrm{~nm}$ of violet-blue light spectrum only, so it does not affect the quality of scotopic vision. It has a single piece, aspheric optic and a 360-degree square edge. The optic was designed with negative spherical aberration to compensate for the cornea's positive spherical aberration. The IOL has " $\mathrm{C}$ " loop haptics with an overall diameter of $13.00 \mathrm{~mm}$ and an optic size of $6.00 \mathrm{~mm}$. The Abbe value is 49 in order to reduce chromatic aberrations, and the refractive index is 1.48 (5).

\section{Statistical Analysis}

Statistical analysis was performed using SPSS version 20 (SPSS Inc., Chicago, IL, US). Mean ( \pm standard deviation) was reported for continuous variables. Median (minimum, maximum) was reported for near visual acuity (Jaeger). Following tests of normality using ShapiroWilks test, Friedman analysis and Wilcoxon signed-ranks test were used to evaluate differences in visual acuity at the follow-up visits.

\section{Results}

Forty-nine eyes (25 right and 24 left) of 49 patients (31 male and 18 female) were included in the study, The mean age of patients was 68.2 years, with a range of 40-84 years.

\section{Visual Acuity}

The visual outcomes are presented in Table 1 and Figure 1. There was a statistically significant improvement in UDVA and CDVA from 1 week to 1 month (Table 1, $\mathrm{p}=0.007$ ). UDVA and CDVA were stabilized at the $1^{\text {st }}$ month examination, and there was no significant difference between the $1^{\text {st }}$ month and the $3^{\text {rd }}$ and $6^{\text {th }}$ month examinations (Table 1). At $6^{\text {th }}$ month, median DCNVA was J3 (Table 2). The best CDVA and UDVA at $6^{\text {th }}$ months were $20 / 25$ or better in $93 \%$ and $79 \%$ of patients, respectively (Figure 1).

\section{Refractive Outcomes}

The mean spherical equivalent of the manifest refraction (SE) was significantly decreased from the preoperative examination to the $6^{\text {th }}$ month examination (Table $3, p<0.001$ ). Mean SE was stable across the $1^{\text {st }}, 3^{\text {rd }}$, and $6^{\text {th }}$ month examinations, and there were no statistically significant differences between the postoperative examinations. At $6^{\text {th }}$ month, the SE was within $\pm 0.50 \mathrm{D}$ of emmetropia in 36 of 49 eyes (74\%) 
Table 1. Uncorrected and corrected distance visual acuities during follow-up

\begin{tabular}{|c|c|c|c|c|c|c|}
\hline & $\begin{array}{l}\text { Preoperative }(n=49) \\
\text { Mean } \pm \text { SD }\end{array}$ & $\begin{array}{l}1^{\text {st }} \text { week } \\
(n=49) \\
\text { Mean } \pm \text { SD }\end{array}$ & $\begin{array}{l}1^{\text {st }} \text { month } \\
(n=49) \\
\text { Mean } \pm S D\end{array}$ & $\begin{array}{l}3^{\text {rd }} \text { month } \\
(n=49) \\
\text { Mean } \pm S D\end{array}$ & $\begin{array}{l}6^{\text {th }} \text { month } \\
(n=49) \\
\text { Mean } \pm \text { SD }\end{array}$ & $p^{*}$ \\
\hline UDVA (Decimal) & $\mathrm{N} / \mathrm{A}$ & $0.72 \pm 0.24$ & $0.81 \pm 0.20$ & $0.83 \pm 0.18$ & $0.83 \pm 0.19$ & $0.03 * *$ \\
\hline CDVA (Decimal) & $0.33 \pm 0.15$ & $0.89 \pm 0.19$ & $0.98 \pm 0.07$ & $0.97 \pm 0.08$ & $0.97 \pm 0.08$ & $<0.00^{\dagger}$ \\
\hline $\begin{array}{l}\text { UDVA: uncorrected } \\
* \text { Global } p \text { value (ov } \\
* * 1 \text { st } \text { week }-1{ }^{\text {st }} \text { mont }\end{array}$ & $\begin{array}{l}\text { uity, CDVA: corrected dista } \\
\text { mparison) } \\
\text { - }-3^{\text {rd }} \text { month: } p=0.004 ; 1^{\text {s }}\end{array}$ & month: $p=0.00$ & onth-3 $3^{\text {rd }}$ month & $3^{\text {rd }}$ month- $6^{\text {th }} \mathrm{m}$ & 0.962 (Wilcoxo & ranks test) \\
\hline \multicolumn{7}{|c|}{$\begin{array}{l}\text { Treoperative- } 1^{\text {st }} \text { week: } p<0.001 ; 1^{\text {st }} \text { week- } 1^{\text {st }} \text { month: } p<0.001 ; 1^{\text {st }} \text { week }-3^{\text {rd }} \text { month: } p=0.001 ; 1^{\text {st }} \text { week }-6^{\text {th }} \text { month: } p=0.002 ; 1^{\text {st }} \text { month }-3^{\text {rd }} \text { month: } p=0.751 ; 3^{\text {rd }} \text { month- }-6^{\text {th }} \text { month, } p=0.314 \\
\text { (Wilcoxon signed-ranks test) }\end{array}$} \\
\hline
\end{tabular}

Table 2. Uncorrected and distance corrected visual acuities during follow-up

\begin{tabular}{|c|c|c|c|}
\hline & $\begin{array}{l}1^{\text {st }} \text { month }(n=49) \\
\text { Median (min-max) }\end{array}$ & $\begin{array}{l}1^{\text {st }} \text { month }(n=49) \\
\text { Median (min-max) }\end{array}$ & $\begin{array}{l}6^{\text {th }} \text { month }(n=49) \\
\text { Median (min-max) }\end{array}$ \\
\hline UCNVA (Jaeger) & $13(3-14)$ & $13(3-14)$ & $13(3-14)$ \\
\hline DCNVA (Jaeger) & $3(3-19)$ & $3(3-13)$ & $3(3-13)$ \\
\hline
\end{tabular}

\section{Table 3. Spherical equivalent of manifest refraction during follow-up}

\begin{tabular}{|c|c|c|c|c|c|c|}
\hline & $\begin{array}{l}\text { Preoperative } \\
(n=49) \\
\text { Mean } \pm \text { SD }\end{array}$ & $\begin{array}{l}1^{\text {st }} \text { week } \\
(n=49) \\
\text { Mean } \pm \text { SD }\end{array}$ & $\begin{array}{l}1^{\text {st }} \text { month } \\
(n=49) \\
\text { Mean } \pm \text { SD }\end{array}$ & $\begin{array}{l}3^{\text {rd }} \text { month } \\
(n=49) \\
\text { Mean } \pm \text { SD }\end{array}$ & $\begin{array}{l}6^{\text {th }} \text { month } \\
(n=49) \\
\text { Mean } \pm \text { SD }\end{array}$ & $p^{*}$ \\
\hline SE (Diopters) & $-1.60 \pm 2.21$ & $0.15 \pm 0.56$ & $-0.14 \pm 0.55$ & $-0.14 \pm 0.55$ & $-0.15 \pm 0.57$ & $<0.001$ \\
\hline
\end{tabular}

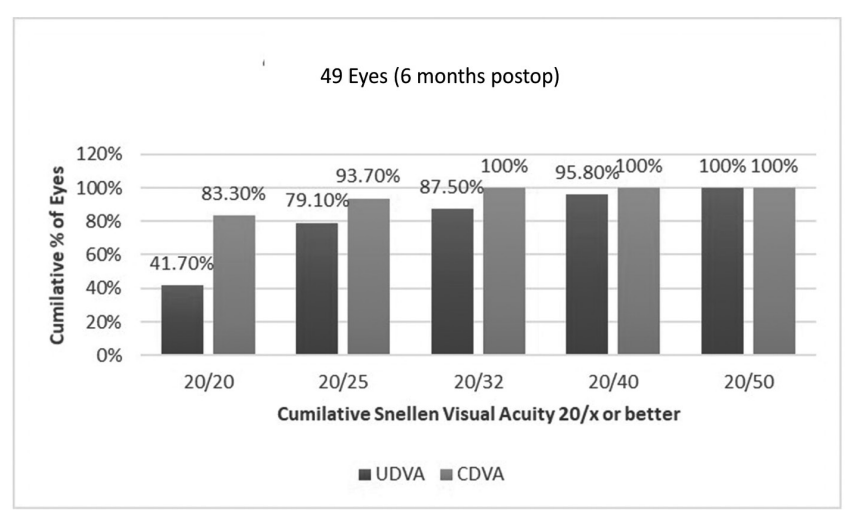

Figure 1. Cumulative monocular UDVA and CDVA at postoperative $6^{\text {th }}$ month

UDVA: uncorrected distance visual acuity, CDVA: corrected distance visual acuity

and within $\pm 1.00 \mathrm{D}$ in 47 of 49 eyes (96\%) (Figure 2). At $6^{\text {th }}$ month, the refractive cylinder was $0.50 \mathrm{D}$ or less in 30 (61.22\%) of 49 eyes and 1.00 D or less in 42 eyes (85.71\%) (Figure 3).

\section{Complications}

No preoperative or postoperative complications were observed in our cohort. No patients lost any lines of DCVA.

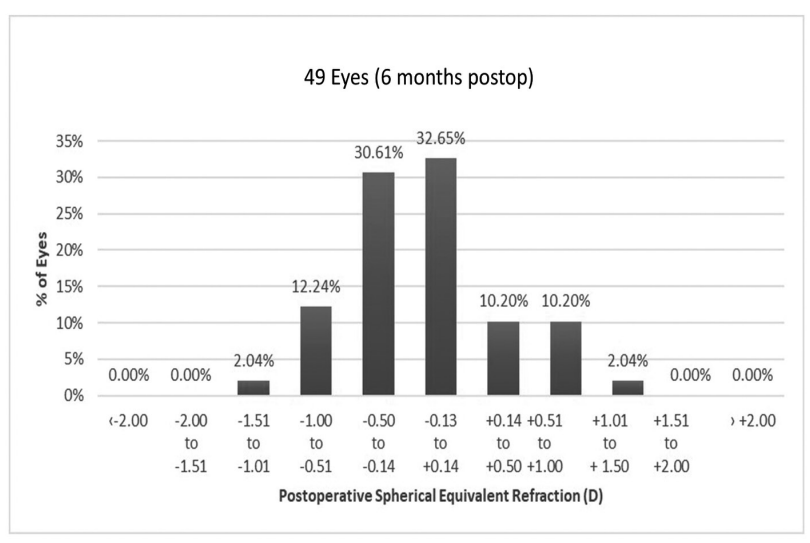

Figure 2. Predictability of refraction at $6^{\text {th }}$ month examination

\section{Discussion}

This retrospective study assessed the refractive and visual outcomes in cataract surgery patients who had hydrophobic aspheric ASHFY600 IOL implantation. The results revealed good visual acuity at postoperative $6^{\text {th }}$ month. Specifically, mean UDVA, CDVA and SE improved significantly over the postoperative period to a UDVA, CDVA and SE of $0.83 \pm 0.19$, $0.97 \pm 0.08$, and $-0.15 \pm 0.57 \mathrm{D}$ at postoperative $6^{\text {th }}$ month, respectively. 


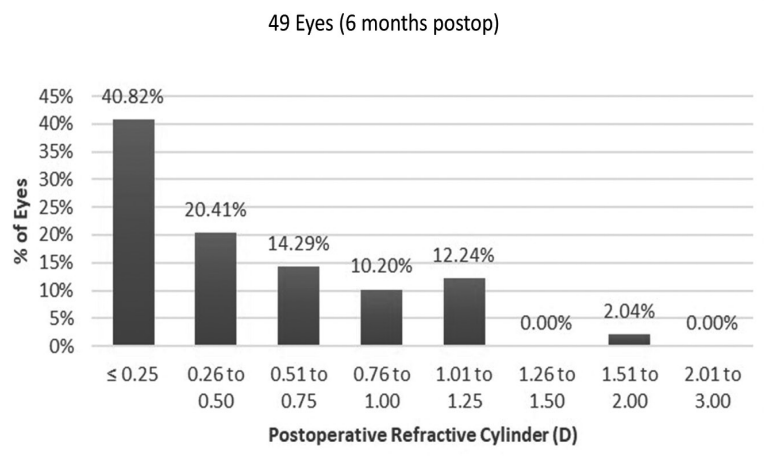

Figure 3. Residual refractive cylinder at $6^{\text {th }}$ month examination

In our study $74 \%$ of the eyes were within $\pm 0,50 \mathrm{D}$ of emmetropia and $96 \%$ (47/49) were within \pm 1.00 D of emmetropia and UCDVA was 20/25 or better in $79 \%$ of the eyes. The Royal College of Ophthalmologists Cataract Surgery Guidelines state that a refractive outcome within \pm 1.00 D of the target should be achieved at $\geq 85 \%$ of the eyes with appropriate formula selection, optical axial length measurement, and optimization of IOL constants (6). Gale et al. (7) have set the refractive benchmark of more than $55 \%$ within $\pm 0.50 \mathrm{D}$ and Hahn et al. (8) has set the refractive benchmark of more than $80 \%$ within $\pm 0.50 \mathrm{D}$. Our refractive results are comparable with these results and benchmarks in the literature.

In our study 7 of 49 (14\%) eyes had astigmatism more than 1.00 D postoperatively and UCVA was relatively lower in these eyes. A $2.75-\mathrm{mm}$ temporal clear corneal incision was used in all patients and this may have resulted in astigmatism of more than $1.00 \mathrm{D}$ in the eyes which already have astigmatism close to $1.00 \mathrm{D}$. Placement of the incision site on the steep corneal meridian or implantation of a toric IOL may have reduced the amount of post-operative astigmatism and increase UCDVA.

UNVA and DCNVA were not satisfactory, however, we consider it reasonable that a monofocal IOL does not result in a satisfactory near vision. Although the IOL is monofocal, it is noteworthy that a significant number of patients had DCNVA of $\mathrm{J} 3$ or more. Relatively better near vision in these eyes might be due to the aspheric nature of the IOL, pseudoaccomodative mechanisms such as a small pupil size (which is frequently seen in this age group) or a combination of these factors. Also, it must be underlined that reading speed was not assessed, thus, these results might not reflect functional near vision accurately.

Retrospective nature and lack of a control group are weaknesses of our study. However, this study adequately shows the safety and efficacy of ASHFY600 IOL. Close and frequent follow-up all consecutive patients implanted with the IOL and having follow-up values of all patients are the strong sides of this study.

\section{Conclusion}

In conclusion, this preliminary study shows that ASHFY600 IOL provides excellent UDVA, CDVA and refractive stability.

Ethics Committee Approval: The approval was obtained from the Haydarpaşa Numune Training and Research Hospital Clinical Research Ethics Committee (approval number: HHEAH-KAEK 2017/193).

Informed Consent: Retrospective study.

Peer-review: Externally peer-reviewed.

Author Contributions: Concept - D.Y., A.D., B.A., M.T., O.Ö., U.Ü., A.A., A.D.; Design - D.Y., A.D., B.A., M.T., O.Ö., U.Ü., A.A., A.D.; Supervision - D.Y., A.D., B.A., M.T., O.Ö., U.Ü., A.A., A.D.; Resources - A.A., A.D. B.A.; Materials - D.Y., A.D., M.T., O.Ö., U.Ü.; Data Collection and/or Processing - D.Y., A.D., M.T., O.Ö., U.Ü.; Analysis and/or Interpretation - D.Y., A.D., B.A., M.T., O.Ö., U.Ü., A.A., A.D.; Literature Search - M.T., O.Ö., U.Ü.; Writing Manuscript D.Y., A.D., B.A., M.T., O.Ö., U.Ü., A.A., A.D.; Critical Review - D.Y., A.D., B.A., M.T., O.Ö., U.Ü., A.A., A.D.

Conflict of Interest: No conflict of interest was declared by the authors.

Financial Disclosure: The authors declared that this study received no financial support.

\section{References}

1. Mainster MA, Sparrow JR. How much blue light should an IOL transmit? Br J Ophthalmol 2003; 87: 1523-9.

2. Symes RJ, Cuthbertson FM. Blue-blocking intraocular implants should be used routinely during phacoemulsification surgery--yes. Eye (Lond) 2012; 26: 1397-9.

3. Zhu XF, Zou HD, Yu YF, Sun Q, Zhao NQ. Comparison of Blue Light-Filtering IOLS and UV Light-Filtering IOLs for Cataract Surgery: A Meta-Analysis. PLoS One 2012; 7: e33013.

4. Mainster MA. Violet and blue light blocking intraocular lenses: photoprotection versus photoreception. Br J Ophthalmol 2006; 90: 784-92.

5. EyeCryl Plus (Natural Yellow Hydrophobic Series) Technical Specifications for Model ASHFY600. http://www.biotechvisioncare.com/home/ophthalmic/ cataract_products/intraocular_lenses/hydrophobic_lenses.shtml. Accessed 10 Aug 2017.

6. The Royal College of Ophthalmologists Cataract Surgery Guidelines. [Online] 2010. https://www.rcophth.ac.uk/wp-content/uploads/2014/12/2010-SCI069-Cataract-Surgery-Guidelines-2010-SEPTEMBER-2010.pdf. Accessed 10 Aug 2017.

7. Gale RP, Saldana M, Johnston RL, Zuberbuhler B, McKibbin M. Benchmark standards for refractive outcomes after NHS cataract surgery. Eye (Lond) 2009; 23: 149-52.

8. Hahn U, Krummenauer F, Kölbl B, Neuhann T, Schayan-Araghi K, Schmickler $S$, et al. Determination of valid benchmarks for outcome indicators in cataract surgery: a multicenter, prospective cohort trial. Ophthalmology 2011; 118: 2105-12. 